REPORTS OF MORPHOLOGY
Official Journal of the Scientific Society of Anatomists,
Histologists, Embryologists and Topographic Anatomists
of Ukraine

\title{
General phenotypological picture of the finger dermatoglyphics of Ukrainian men: the contribution of individual regions
}

Gunas V.I. ${ }^{1}$, Mishalov V.D. ${ }^{2}$, Serebrennikova O.A. ${ }^{1}$, Klimas L.A. ${ }^{1}$

${ }^{1}$ National Pirogov Memorial Medical University, Vinnytsya, Ukraine

${ }^{2}$ National Medical Academy of Postgraduate Education named after P.L. Shupyk, Kyiv, Ukraine

\section{ARTICLE INFO}

Received: 2 October, 2018

Accepted: 1 November, 2018

UDC: $340.6: 572.524 .12: 616$.

$055.1(477)$

\section{CORRESPONDING AUTHOR}

e-mail: freekozak1@gmail.com Gunas V.I.

\begin{abstract}
The formation of regional gene pools and the contribution of each of them to the formation of the population of Ukraine remains an actual topic of the present. The purpose of the study is to assess the contribution of each of the 5 territorial-administrative regions of Ukraine to the overall phenotypological picture of the finger dermatoglyphics of the male population of Ukraine. By the method of $\mathrm{H}$. Cummins and Ch. Midlo conducted a dermatological study of 400 practically healthy men from 5 administrative-territorial regions of Ukraine. Statistical processing of the obtained results was carried out in the package "Statistica 6.1" using nonparametric methods. It was established that among practically healthy men of Ukraine without administrative-territorial distribution and representatives of various administrative-territorial regions $37.96 \%$ of reliable or tendencies of differences of information indicators of finger dermatoglyphics were revealed out of 108 analyzed parameters. The best information ability of quantitative $(47.83 \%)$ indicators of finger dermatoglyphics was proved in comparison with qualitative (35.29\%) indicators. The greatest number of differences in the signs of finger dermatoglyphics is established between men without division into administrativeterritorial regions and men, residents of the southern (11.11\%), eastern (10.19\%) and western (8.33\%) regions of Ukraine. Less number of differences from the overall picture of the country are found in men in the northern region, its rates significantly differed almost at the level of error and amounted to $5.56 \%$. Indicators of finger dermatoglyphics of men in the central region in general do not differ significantly from those in general in Ukraine. Thus, the dominant component in the general phenotypological picture of finger dermatoglyphics of the male population of Ukraine has a central region whose rates were not significantly different from the country's total, and to a lesser extent, the dermatoglyphics of the northern region. The obtained results indicate that the main genetic landscape of the gene pool of Ukraine, according to finger dermatoglyphics, forms the central and northern regions of the country.

Keywords: finger dermatoglyphics, males, administrative-territorial regions of Ukraine, contribution of separate regions.
\end{abstract}

\section{Introduction}

Since its inception as a separate section of morphology, dermatoglyphics is of considerable interest to scientists from various fields of science. It found her application not only in forensics but also in practical medicine, allowing to detect or predict the risk of certain diseases [7].

Today, one of the promising areas of dermatoglyphics is its possible application for the purpose of identifying a person's regional and ethnic belongings. Particularly relevant this method of investigation may be to determine the place of origin of illegal migrants, identify victims of armed conflicts, and so on.
It is worth noted that the special interest for practical application will be full bases, which will include a database of the characteristics of dermatological indicators of the population of all ethnic groups and regions of the country. Therefore, scientists around the world are actively conducting research of this type, with the ultimate goal - the formation of a complete database $[1,3,12,13,15,19,20,23]$.

Thus, Abue A.D., Rose C. and Courage N. in their work in 2018 revealed the features of dermatological attributes in the tribe of Ntamante, living in southern Nigeria. 200 people aged from 18 to 68 were involved, which in the third 
generation are representatives of this ethnic group. The statistical analysis revealed the following distribution of the frequency of patterns among men: ulnar loops $12.6 \pm 9.2$, arches $4.7 \pm 2.8$, whorls $3.3 \pm 3.0$ and radial loops $0.1 \pm 0.4$; in women - ulnar loops $9.1 \pm 9.7$, whorls $6.4 \pm 4.4$, arcs $4.9 \pm 3.8$ and radial loops $1.0 \pm 1.6$ [2].

S. Biswas [5] studied palmar and finger dermatoglyphic indices among the ethnic group of Dhimals living in northern Bengal (India). The patterns of patterns were: whorls $55.1 \%$, $50.2 \%$, loops $42.16 \%, 48.24 \%$ and arches $2.75 \%, 1.57 \%$ for men and women, respectively. The density of patterns was 15.24 for men and 14.86 for women. Total ridges count was $162.18 \pm 3.38$.

The features of dermatoglyphic indices and their manifestations of sexual dimorphism among the population of Sardinia [8] were determined. The higher values of ridge count b-c, c-d on the right hand and a-b, a-d indicators on the left hand were revealed. Men showed higher rates of a$\mathrm{b}, \mathrm{c}-\mathrm{d}$ on their right hand than in women.

Studies conducted in 2011 by Jaja B.N.R., Olabiyi O. and Noronha C.C. [11] found that the rates of whorl detection, the total ridge count, and the palmar ridge count A-B indicate a close affinity of the Nigerian tribe Ogoni to the tribes of southern Ghana, indicating possible historical migration of this ethnic group.

Features of the indexes of finger and palm prints were found for the Muzeina Bedouin living in the south of the Sinai Peninsula [14]. The highest index of whorl frequency on the fourth finger, ulnar loop on the third finger of both hands for both sexes was revealed.

However, in Ukraine, these studies are few, have a regional character and do not allow creating one, integral image of the dermatoglyphic population $[16,17]$.

The study of the gene pool of the population of Ukraine is important not only for the country itself, but, as Otevska O.M. [25] notes, due to his position, for the study of the European gene pool too.

The general structure of the gene pool of Ukraine historically consisted of the genetic features of the population in different parts of the ethnic range, caused by different conditions of the intensity of international contacts and migration processes, the level of urbanization and the nature of the natural reproduction of the population, the share of the presence of impurities of other nationalities. In populationgenetic studies, various markers are used: physiological, immuno-biochemical, DNA markers, quasi-genetic (distribution of surnames) [10, 21, 24]. Among them, a simple and powerful analytical tool - a method of dermatoglyphics takes a special place, which allows determining the contribution to the formation of the ethnic community of the indigenous and inborn population that was involved in marital ties with the indigenous population. It should be noted that the fragmentation of the literary data [22] does not allow to make a complete picture of the gene pool of Ukrainians in general and the contribution of each of the five territorial administrative regions of Ukraine to the general phenotypological picture of the finger dermatoglyphics of the male population of Ukraine, which became the goal of our work.

\section{Materials and methods}

Researched fingerprints of 400 practically healthy men aged from 19 to 35 years in the third generation residents of the relevant regions of Ukraine: 72 - from the north (Zhytomyr, Kyiv, Chernihiv, Sumy regions), 47 - from the south (Odessa, Mykolaiv, Kherson, Zaporizhzhya region and AR Crimea), 165 - from the central (Vinnytsia, Cherkasy, Kirovohrad, Poltava and Dnipropetrovsk regions), 71 - from the west (Volyn, Rivne, Lviv, Chernivtsi, Ternopil, Khmelnytsky, Transcarpathian and Ivano-Frankivsk regions), 45 residents from the eastern (Kharkiv, Lugansk, Donetsk regions) regions. The dermatological study was performed according to $\mathrm{H}$. Cummins and Ch. Midlo [6].

Fingerprints obtained by using ink on a sheet of paper [9]. Analysis subject 108 indicators of digital dermatoglyphics, of which 85 related to quality indicators and 23 indicators related to quantitative traits. Bioethics Committee of National Pirogov Memorial Medical University, Vinnytsya found that the studies are not contrary to the fundamental bioethical standards of the Helsinki Declaration, the European Convention on Human Rights and Biomedicine (1977), the relevant provisions of the WHO and the laws of Ukraine (protocol number 8 from 10.09.2013).

Statistical processing of the obtained results was carried out in the package "Statistica 6.1" using nonparametric methods.

\section{Results}

Among the practically healthy men of the general group and representatives of the northern region of Ukraine, the following reliable or trends of the differences in the indicators of finger dermatoglyphics are established:

among the qualitative indicators, in men of the northern region, the percentage of central pockets on the I $(36.1 \%$ versus $24.3 \%, p<0.05)$, III (19.4\% vs. $10.5 \%, p<0.05)$ and IV (45.8\% against $33.8 \%, p=0.051)$ fingers of the right hand and IV of the fingers of the left hand $(33.3 \%$ vs. $21.0 \%, p<0.05)$ is higher than in total group, as well as a higher percentage of double loop on the IV finger of the left hand $(26.4 \%$ vs. $16.3 \%, p<0.05$ );

among quantitative indicators - reliable or trends of differences are not established;

among asymmetries of qualitative and quantitative indices - in men of the northern region less than in the general group, the absolute value of the asymmetry of the ridge count of the III finger $(0.278 \pm 4.514$ versus $0.970 \pm 0.245$ ridges, $\mathrm{p}<0.05)$, asymmetry, in contrast, right-handed.

Among the practically healthy men of the general group and representatives of the southern region of Ukraine, the following reliable or trends of the differences in the indicators of finger dermatoglyphics are established: 
among the qualitative indicators - in men of the southern region, the percentage of the presence of whorl on the right IV finger $(17.0 \%$ versus $8.3 \%, p=0.052)$ of the hand, and the arches on the III fingers as the right ones $(31.9 \%$ vs. $18.8 \%$, $p<0.05)$ and left $(25.5 \%$ vs. $14.8 \%, p=0.059)$ hands, as well as a lower percentage of ulnar loop on the II right finger $(10.6 \%$ versus $26.3 \%, p<0.05)$, double loop on the I $(4.3 \%$ against the $16.3 \%, p<0.05)$, central pocket on the II $(6.4 \%$ vs. $19.5 \%, p<0.05)$ and random pattern on III ( $0 \%$ vs. $6.5 \%$, $p=0.072$ ) fingers of the left hand higher than in total group;

among the quantitative indicators - in men of the southern region less than in the general group, the value of the ridge count of the III finger as the right $(9.128 \pm 7.058$ versus $11.37 \pm 6.62$ ridges, $p<0.05)$ and the left $(10.36 \pm 6.82$ versus $12.37 \pm 6.55$ ridges, $p<0.05)$, as well as ridge count of I finger $(14.55 \pm 7.55$ versus $16.61 \pm 7.53$ ridges, $p=0.078)$, total ridge count $(60.09 \pm 23.97$ versus $67.90 \pm 25.67$ ridges, $p<0.05)$ of left hand and total ridge count $(122.6 \pm 46.4$ versus $136.6 \pm 49.4$ ridges, $p=0.064$ );

among asymmetries of qualitative and quantitative indicators - reliable or trends of differences are not established.

Among the practically healthy men of the general group and representatives of the central region of Ukraine, the following reliable or trends of the differences in the indicators of finger dermatoglyphics are established:

among the qualitative indicators, the men in the central region had smaller than the general group, percentage of the presence of whorl on the IV fingers $(4.2 \%$ vs. $8.3 \%$, $\mathrm{p}=0.085$ ) of the right hand and arches on the II left fingers (18.2\% vs. $25.5 \%, p=0.063$ );

among quantitative indicators - reliable or trends of differences are not established;

among the asymmetries of qualitative and quantitative indicators - in men of the central region less than in the general group, the value of asymmetry by the type of pattern on the I finger $(46.7 \%$ vs. $54.8 \%, p=0.080)$.

Among the practically healthy men of the general group and representatives of the western region of Ukraine, the following reliable or trends of the differences in the index of finger dermatoglyphics are established:

among the qualitative indicators, men in the western region had a greater percentage of the presence of ulnar loops on the I fingers $(56.3 \%$ vs. $42.5 \%, p<0.05)$ and the arches on the $V$ fingers $(19.7 \%$ vs. $11.3 \%, p<0.05)$ of the right hand, as well as a higher percentage of the random pattern on the III finger $(12.7 \%$ vs. $6.5 \%, p=0.067)$ and the double loop on the $\mathrm{V}$ finger $(7.0 \%$ vs. $2.0 \%, p<0.05)$ of the left hand;

among the quantitative indicators - in men of the western region less than in the general group, the value of the ridge count of the IV right finger (13.35 \pm 6.87 versus $15.17 \pm 6.39$ ridges, $p<0.05)$ and the left $(13.90 \pm 5.83$ versus $15.27 \pm 6.03$ ridges, $p=0.078)$ hands, as well as $V$ finger $(10.94 \pm 6.94$ versus $12.83 \pm 6.02$ ridges, $p<0.05$ ) of the right hand;

among the asymmetry of qualitative and quantitative indicators - in men of the western region higher than in the general group, the value of the asymmetry of the ridge count of the II finger $(1.493 \pm 5.712$ versus $0.168 \pm 5.841$ ridges, $p=0.078$ ) and less of the asymmetry value according to the type of the fingerprint pattern of $\mathrm{V}$ finger $(54.9 \%$ against $66.0 \%$, $\mathrm{p}=0.073$ ).

Among the practically healthy men of the general group and representatives of the eastern region of Ukraine, the following reliable or trends of the differences in the indicators of finger dermatoglyphics are established:

among the qualitative indicators, the men of the eastern region had a higher percentage of arc on the right I finger $(13.3 \%$ versus $6.0 \%, p=0.065)$ and the ulnar loop $(82.2 \%$ versus $61.8 \%, p<0.01)$ and random the pattern on the III finger ( $0 \%$ vs. $6.5 \%, p=0.079)$, the radial loop on the IV finger (2.2\% versus $0.3 \%, p=0.085)$, ulnar $(84.4 \%$ versus $72.0 \%$, $p=0.076)$, and the radial $(2.2 \%$ against the $0.3 \%, p=0.085)$ loops on the left $\mathrm{V}$ finger, as well as a lower percentage of the double loop on the right I finger $(6.7 \%$ vs. $16.8 \%, p=0.079)$ and the central pocket of the right $\mathrm{V}$ finger $(0 \%$ vs. $9.8 \%$, $\mathrm{p}<0.05)$ and on a I finger ( $4.4 \%$ vs. $13.8 \%, p=0.075)$, on the IV finger $(8.9 \%$ vs. $21.0 \%, p=0.054)$ of the left hand then in the total group;

among the quantitative indicators - the men of the eastern region had less than in the general group, the value of the ridge count on the right I finger $(15.78 \pm 7.35$ versus $18.63 \pm 7.19$ ridges, $p<0.05$ );

among asymmetries of qualitative and quantitative indicators - reliable or trends of differences are not established.

Thus, the analysis of the differences in the indicators of finger dermatoglyphics between practically healthy men of Ukraine without administrative-territorial distribution and representatives of various administrative-territorial regions revealed that:

- the finger dermatoglyphics of the northern administrative-territorial region significantly differs from that in the country as a whole in terms of 4 indicators of qualitative characteristics and 1 indicator of asymmetry of the quantitative trait, and also shows a tendency for differences in 1 indicator of qualitative trait;

- the finger dermatoglyphics of the southern administrative-territorial region significantly differs from the country as a whole in terms of 4 indicators of qualitative and 3 indicators of quantitative characteristics, and also shows a tendency for differences in 3 indicators of qualitative and 2 indicators of quantitative attributes;

- the finger dermatoglyphics of the central administrativeterritorial region is not significantly different from that of the country as a whole, and also shows a tendency for differences in 2 indicators of qualitative characteristics and 1 indicator of asymmetry of a qualitative characteristic;

- finger dermatoglyphics of western administrativeterritorial region significantly different from that in the whole country by three indicators of quality and 2 indices of quantitative traits, and shows a tendency difference by 1 
indicator of quality, 1 indicator of quantitative trait, 1 indicator of the asymmetry of quality features and 1 indicator of the asymmetry quantity signs;

- finger dermatoglyphics of eastern administrativeterritorial region significantly different from that in the whole country by 2 qualitative parameters and 1 indicator of quantitative characteristics and shows trend differences by 8 indicators of qualitative traits.

\section{Discussion}

An analysis of the differences between the indicators of finger dermatoglyphics among practically healthy men of Ukraine without administrative-territorial distribution and representatives of various administrative-territorial regions revealed $41(37.96 \%)$, and without trends - $20(18.52 \%)$ of the informative indicators out of 108 analyzed and demonstrated the best informative ability of quantitative ((11 $(47.83 \%))$, and without trends (7 (30.43\%)), indexes of finger dermatoglyphics compare to qualitative ((30 (35.29\%) and without trends - $(13(15.29 \%))$ indicators.

The greatest number of differences in the signs of finger dermatoglyphics in terms of qualitative and quantitative indicators were established between men, inhabitants of Ukraine without division into administrative-territorial regions and men, residents of the southern ((12 $(11.11 \%)$ indicators, $7(6.48 \%)$ of which are reliable $))$, eastern $((11)(10.19 \%)$ indicators, $3(2.78 \%)$ of which are reliable $))$ and western ((9 $(8.33 \%)$ indicators, $5(4.63 \%)$ of which are reliable)) regions of the country. Among the regions that show differences from the general picture of the country, the northern region is least diverse, its rates significantly differed almost at the level of error and amounted to $5.56 \%$. At the same time, the indicators of finger dermatoglyphics of men in the central region do not significantly differ from such indicators in Ukraine (Fig. 1).

Thus, the core of the general phenotypological picture of the finger dermatoglyphics of the male population of Ukraine makes the central region. The expressed peculiarity of finger dermatoglyphics of Ukrainian men in the central region is confirmed by their differences from the southern, eastern and western regions, which is covered in our previous study [18]. The localization of the nucleus of peculiar values within the range of the ethnic group, and not at its borders, indicates that not the migration processes, but the peculiarities of their own self-development, form the basic genetic landscape of its gene pool [4]. The results obtained by us are confirmed by the data of the study of the distribution of Ukrainian surnames taking into account the administrative and geographical zoning of the territory of Ukraine according to the index of random isonomy (the frequency of marriages between individuals having the same surname) and calculated on its basis the indicator of random inbreeding

\section{References}

[1]Abue, A. D., Christopher, R., \& Sunday, A. (2018). The Qualitative Dermatoglyphics Patterns in Both Hands for Males and Females in Ubang Clan Cross River State Nigeria. Advances in Anthropology, 8, 73-81. https://doi.org/10.4236/aa.2018.82004

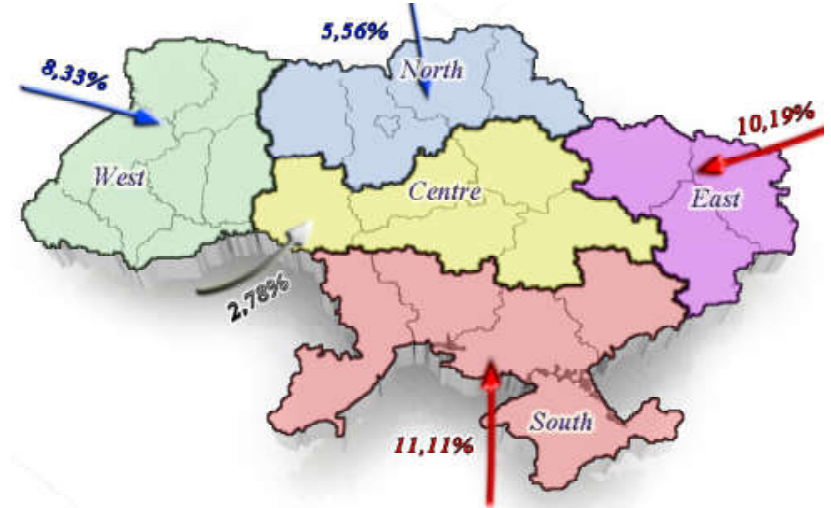

Fig. 1. Regional contribution of finger dermatoglyphics to the general phenotypological picture of dermatoglyphics of men in Ukraine.

(marriages between relatives) [10]. The authors proceeded from the fact that surnames are the most attractive among quasi-genetic markers, since in their most important manifestations - transmission in generations, distribution in populations - they resemble genes. In the given work it is shown that the minimum value of the index of random homonymity is characteristic for the southern region $(2.2 \mathrm{x}$ $10-4)$, eastern (2.7 x 10-4) and western (2.4 x 10-4), higher values in the central $(3.2 \times 10-4)$ and northern $(3.4 \times 10-4)$ regions. Similar data were obtained from the index of inbreeding: its highest value was observed in the northern (8.5 $\times 10-5)$ and central $(7.9 \times 10-5)$ regions, the lowest in the southern (5.6 $\times 10-5)$, the eastern $(6.7 \times 10-5)$ and the western (6.1 $\times 10-5)$ occupy an intermediate position.

Thus, the indicators of the genetic contribution of certain administrative-territorial regions in the overall picture of the country's finger dermatoglyphic are indirectly indicative of a significant coincidence with inbreeding indicators calculated on the basis of the names of the surnames, and therefore further research may be aimed at identifying correlations between them.

\section{Conclusions}

1. The dermatoglyphic populational typological picture of somatically healthy men of Ukraine is formed mainly due to the genetic contribution of people in the central region, since their indices do not significantly differ from such indicators in general in Ukraine.

2. Indicators of finger dermatoglyphics of men, residents of southern, eastern and western administrative-territorial regions differ from the indicators in general in Ukraine, the differences in the order of decrease make up $11.11 \%$, $10.19 \%, 8.33 \%$ of indicators, respectively. The northern region is the least diverse, and the difference between its indicators and such in country in total is only $5.56 \%$.

[2] Abue, A. D., Rose, C., \& Courage, N. (2018). Analyses of Dermatoglyphic Patterns in Ntamante, Boki Local Government Area (LGA) of Cross River State, Nigeria. Advances in Anthropology, 8(3), 83-90. doi: 10.4236/aa.2018.83005 
[3] Abue, A. D., Ujaddughe, M., \& Kpela, M. T. (2013). The arch pattern dermatoglyphics on the toes of Hausa ethnic group of Nigeria. Advances in Anthropology, 3(4), 237-239. http:// dx.doi.org/10.4236/aa.2013.34033

[4] Balanovskiy, O. P., \& Tehako, O. V. (2008). The gene pool of Belarusians according to data on three types of genetic markers - autosomal, mitochondrial, Y chromosomes. Current issues of anthropology, 2, 53-65.

[5] Biswas, S. (2011). Finger and palmar dermatoglyphic study among the Dhimals of North Bengal, India. The Anthropologist, 13(3), 235-238. https://doi.org/10.1080/ 09720073.2011 .11891202

[6] Cummins, H., \& Midlo, Ch. (1961). Finger Prints, Palms and Soles. An Introduction to Dermatoglyphics. Philadelphia.

[7] Dmytrenko, S. V., Klimas, L. A., Kushnir, V. A., Serebrennikova O. A., \& Serheta, I. (2018). Features of quantitative indicators of finger and palmar dermatoglyphics in males and females with ichthyosis. Biomedical and Biosocial Anthropology, (32), 48-55. https://doi.org/https://doi.org/10.31393/bba32-2018-07

[8] Floris, G. (2015). Palmar Intertriradial Ridge Counts in Sardinians. Advances in Anthropology, 5(3), 137-143. http://dx.doi.org/ 10.4236/aa.2015.53012

[9] Gladkova, T. D. (1966). Skin patterns of the hand and foot of monkeys and humans. M.: Science. https://www.twirpx.com/ file/1246327/

[10] Gorpinchenko, M., \& Atramentova, L. (2015). Population-genetic characteristics of the population of Ukraine, obtained with the use of surnames. Bulletin of the Taras Shevchenko National University of Kyiv. Biology, 69, 68-72. ISSN 1728-3817.

[11] Jaja, B. N. R., Olabiyi, O., \& Noronha, C. C. (2011). Dermatoglyphics of the Ogoni of Nigeria and its historiographic implications. Anthropologischer Anzeiger, 68(2), 175-183. https://doi.org/10.1127/0003-5548/2011/0057

[12] Jami, J., \& Limbu, D. K. (2015). Digital and Palmar Dermatoglyphics of the Bhoi Khasis of Umden Village, Ri-Bhoi District, Meghalaya. Journal of Life Sciences, 7(1-2), 12-14. https://doi.org/10.1080/09751270.2015.11885231

[13] Kapoor, N., \& Badiye, A. (2015). Digital dermatoglyphics: A study on Muslim population from India. Egyptian Journal of Forensic Sciences, 5(3), 90-95. http://dx.doi.org/10.1016/ j.ejfs.2014.08.001

[14] Karmakar, B., \& Kobyliansky, E. (2011). Finger and palmar dermatoglyphics in Muzeina Bedouins from South Sinai: qualitative traits. Papers on Anthropology, 20, 146-159. https:/ /doi.org/10.12697/poa.2011.20.16
[15] Koneru, A., Hallikeri, K., Nellithady, G. S., Rekha, K., Prabhu, S., \& Niranjan, K. C. (2014). Assessment and comparison of fingerprints between Kerala and Manipuri populations of India: A forensic study. Journal of Advanced Clinical and Research Insights, 1(2), 42-45. doi: 10.15713/ins.jcri.12

[16] Kozan, N. M., \& Kotsyubynska, Y. Z. (2015). Sexual Dimorphism of Digital Dermatoglyphic Parameters among Population of Boyko Ethnic Group. Galician Medical Journal, 22(3), 161163.

[17] Kozan, N. N. (2017). Forensic medical identification of an ethno-territorial affiliation of an unknown person with dermatoglyphic parameters of palms with discriminant analysis. Reports of Vinnytsia National Medical University, 21(1 (2)), 252-255.

[18] Mishalov, V. D., Serebrennikova, O. A., Klimas, L. A., \& Gunas, V. I. (2018). Regional trends indicators finger dermatoglyphics among modern Ukrainians. Biomedical and biosocial anthropology, 30, 5-12. doi: 10.31393/bba30-2018-01

[19] Namouchi, I. (2011). Anthropological significance of dermatoglyphic trait variation: an intra-Tunisian population analysis. International Journal of Modern Anthropology, 1(4), 12-27. doi: 10.4314/ijma.v1i4.1

[20] Paul, C. W., \& Paul, J. N. (2017). Gender Variation Studies at Level 2 Dermatoglyphic Details of the Kalabari Ethnic Group in Rivers State, Nigeria. Sch. J. App. Med. Sci., 5(11A), 42974301. doi: 10.21276/sjams.2017.5.11.3.

[21] Pshenichnikov, A. S. (2007). The structure of the gene pool of Ukrainians according to the data on polymorphism of mitochondrial DNA and Y chromosome (PhD thesis). http:// earthpapers.net/

[22] Segeda, S. P. (2001). Anthropological composition of the Ukrainian people: ethnogenetic aspect. Publishing house named after Olena Teliha.

[23] Sen, J., Kanchan, T., \& Mondal, N. (2011). A comparison of palmar dermatoglyphics in two ethnic Indian populations of north Bengal, India. Journal of forensic sciences, 56(1), 109117. https://doi.org/10.1111/j.1556-4029.2010.01554.x

[24] Sorokina, I. N. (2005). The study of population-demographic structure of the population of the Belgorod region ( $\mathrm{PhD}$ thesis). http://www.dslib.net/

[25] Utaevska, O. M. (2017). Genetic fund of Ukrainians under various systems of genetic markers: origin and place on the European genetic space (Doctoral dissertation). http:// nrcrm.gov.ual

\section{ЗАГАЛЬНА ФЕНОТИПОЛОГІЧНА КАРТИНА ПАЛЬЦЕВОЇ ДЕРМАТОГЛІФІКИ ЧОЛОВІКІВ УКРАЇНИ: ВНЕСОК ОКРЕМИХ PETIOHIB}

Гунас В.І., Мішалов В.Д., Серебреннікова О.А., Клімас Л.А.

Становлення регіональних генофондів і внесок кожного з них у формування народонаселення України залишається актуальною темою сьогодення. Мета дослідження - оцінити внесок кожного з 5 територіально-адміністративних регіонів України до загальної фенотипологічної картини пальцевої дерматогліфріки чоловічого населення України. За методикою H. Ситтіns $i$ Ch. Midlo проведено дерматогліфрічне дослідження 400 практично здорових чоловіків із 5 адміністративно-територіальних регіонів України. Статистична обробка отриманих результатів проведена в пакеті "Statistica 6.1" з використанням непараметричних методів. Встановлено, що між практично здоровими чоловіками України без адміністративнотериторіального розподілу та представниками різних адміністративно-територіальних регіонів виявлено 37,96 \% достовірних, або тенденцій відмінностей інформаційно здатних показників пальцевої дерматогліфіки зі 108 проаналізованих показників. Доведено кращу інфрормаційну здатність кількісних (47,83 \%) показників пальцевої дерматогліфріки порівняно 3 якісними (35,29 \%) показниками. Найбільшу кількість відмінностей ознак пальцевої дерматогліфріки встановлено між чоловіками без поділу на адміністративно-територіальні регіони і чоловіками, мешканиями південного $(11,11 \%)$, східного (10,19 \%) та західного (8,33 \%) регіонів України. Меншу кількість відмінностей від загальної картини по країні встановлено у чоловіків північного регіону, його показники достовірно відрізнялись практично на рівні похибки і становили 5,56\%. Показники пальцевої дерматогліфіки чоловіків центрального регіону взагалі достовірно не відрізняються від таких показників загалом 
по Україні. Таким чином, домінуючою складовою в загальній френотипологічній картині пальцевої дерматогліфіки чоловічого населення України є така центрального регіону, показники якого достовірно не відрізнялися від загальних по країні, а також, в дещо меншій мірі, - дерматогліфріка північного регіону. Отримані результати вказують на те, що основний генетичний ландшафт генофонду України, за даними пальцевої дерматогліфріки, фоормують центральний та північний регіони країни. Ключові слова: пальцева дерматогліфіка, чоловіки, адміністративно-територіальні регіони України, внесок окремих регіонів.

\section{ОБЩАЯ ФЕНОТИПОЛОГИЧЕСКАЯ КАРТИНА ПАЛЬЦЕВОЙ ДЕРМАТОГЛИФИКИ МУЖЧИН УКРАИНЫ: ВКЛАД ОТДЕЛЬНЫХ РЕГИОНОВ}

Гунас В.И., Мишалов В.Д., Серебренникова О.А., Климас Л.А.

Становление региональных генофондов и вклад каждого из них в формирование народонаселения Украины остается актуальной темой сегодняшнего дня. Цель исследования - оценить вклад каждого из 5 территориально-административных регионов Украины в общую френотипологическую картину пальцевой дерматоглифики мужского населения Украины. По методике H. Cummins u Ch. Midlo проведено дерматоглифрическое исследования 400 практически здоровых мужчин из 5 административно-территориальных регионов Украины. Статистическая обработка полученных результатов проведена в пакете "Statistica 6.1" с использованием непараметрических методов. Установлено, что между практически здоровыми мужчинами Украины без административно-территориального деления и представителями различных административнотерриториальных регионов обнаружено 37,96\% достоверных или тенденций различий информационно способных показателей пальцевой дерматоглифики из 108 проанализированных показателей. Доказано лучшую информационную способность количественных (47,83\%) показателей пальцевой дерматоглифики по сравнению с качественными (35,29\%) показателям. Наибольщее количество различий признаков пальцевой дерматоглифики установлено между мужчинами без разделения на административно-территориальные регионы и мужчинами, жителями южного (11,11\%), восточного (10,19\%) и западного (8,33\%) регионов Украины. Меньщее количество отличий от общей картины по стране установлено у мужчин северного региона, его показатели достоверно отличались практически на уровне погрешности и составили 5,56\%. Показатели пальцевой дерматоглифрики мужчин центрального региона вообще достоверно не отличаются от таких показателей в целом по Украине. Таким образом, доминирующей составляющей в общей фенотипологической картине пальцевой дерматоглифики мужского населения Украины есть такая центрального региона, показатели которого достоверно не отличались от общих по стране, а также, в несколько меньшей степени - дерматоглифика северного региона. Полученные результаты указывают на то, что основной генетический ландшафтт генофонда Украины, по данным пальцевой дерматоглифики, фрормируют центральный и северный регионы страны.

Ключевые слова: пальцевая дерматоглифика, мужчины, административно-территориальные регионы Украины, вклад отдельных регионов. 